\title{
PENEGAKAN HUKUM TINDAK PIDANA KORUPSI PTSL DI DESA SIDOMUKTI KECAMATAN WELERI KABUPATEN KENDAL
}

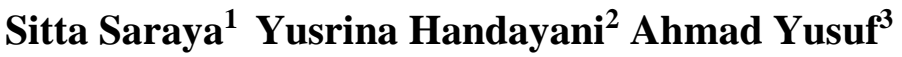 \\ ${ }^{1}$ Dosen Fakultas Hukum Universitas Selamat Sri, Mahasiswa Program Doktor Ilmu Hukum \\ Universitas Islam Sultan Agung \\ E-mail: sittalaw@gmail.com \\ ${ }^{2}$ Fakultas Hukum Universitas Selamat Sri \\ E-mail: rinamifta88@gmail.com \\ ${ }^{3}$ Fakultas Hukum Universitas Selamat Sri \\ E-mail: ahmadyusuf.ay37@gmail.com
}

\begin{abstract}
The State of Indonesia is an agricultural country, which has wide islands, a large expanse of land, so it is better known as the archipelago. The state of Indonesia which is a state of Law and all aspects of people's lives are regulated in laws and regulations, including those regarding land or agrarian matters. The current agrarian law (Before the 1960 LoGA), which should be one of the important tools to build a just and prosperous society, turns out to be the opposite, in fact there are still many things that are contrary to justice and even enter the realm of criminal law. Criminal law in Indonesia, which is considered to have a narrow scope, actually regulates deviations that occur in agrarian provisions, especially with regard to the Corruption Crime of Complete Systematic Land Registration (PTSL), especially in the Kendal Regency area. People who should be assisted in terms of land ownership, are instead made victims of corruption by certain individuals. Agrarian law is not always related to the realm of civil law, because if in reality in the community if a deviation occurs and it enters the realm of criminal law, then deviations from the Complete Systematic Land Registration (PTSL) will be charged with the provisions of criminal law in Indonesia. The purpose of this study is to analyze law enforcement related to the corruption of Complete Systematic Land Registration (PTSL) in Kendal Regency and to find out how criminal responsibility is in the corruption crime of Complete Systematic Land Registration (PTSL).
\end{abstract}

Keywords: Law Enforcement, PTSL Corruption Crimes. 


\begin{abstract}
Abstrak
Negara Indonesia merupakan negara agraris, yang memiliki pulau-pulau yang luas, hamparan tanah yang luas, sehingga lebih dikenal dengan negara kepulauan. Negara Indonesia yang merupakan negara hukum dan segala aspek kehidupan masyarakat diatur dalam peraturan perundang-undangan, termasuk yang mengenai pertanahan atau agraria. Undang-undang agraria saat ini (Sebelum UUPA 1960), yang seharusnya menjadi salah satu alat penting untuk membangun masyarakat adil dan makmur, ternyata sebaliknya, ternyata masih banyak hal yang bertentangan dengan keadilan dan bahkan masuk ke ranah hukum. ranah hukum pidana. Hukum pidana di Indonesia yang dianggap memiliki ruang lingkup yang sempit, sebenarnya mengatur tentang penyimpangan yang terjadi dalam ketentuan agraria, khususnya yang berkaitan dengan Tindak Pidana Korupsi Pendaftaran Tanah Sistematis Lengkap (PTSL), khususnya di wilayah Kabupaten Kendal. Masyarakat yang seharusnya dibantu dalam hal kepemilikan tanah justru dijadikan korban korupsi oleh oknum tertentu. Hukum agraria tidak selalu berkaitan dengan ranah hukum perdata, karena jika dalam kenyataannya di masyarakat jika terjadi penyimpangan dan masuk ke ranah hukum pidana, maka penyimpangan dari Pendaftaran Tanah Sistematis Lengkap (PTSL) akan dikenakan ketentuan. hukum pidana di Indonesia. Tujuan penelitian ini adalah untuk menganalisis penegakan hukum terkait tindak pidana korupsi Pendaftaran Tanah Sistematis Lengkap (PTSL) di Kabupaten Kendal dan untuk mengetahui bagaimana pertanggungjawaban pidana dalam tindak pidana korupsi Pendaftaran Tanah Sistematis Lengkap (PTSL).
\end{abstract}

\title{
Kata Kunci: Penegakan Hukum, Tindak Pidana Korupsi, PTSL.
}

\section{Pendahuluan}

\subsection{Latar Belakang}

Undang-Undang Dasar Republik Indonesia Tahun 1945 menentukan secara tegas bahwa negara Indonesia adalah negara hukum. Sejalan dengan ketentuan tersebut maka salah satu prinsip penting negara hukum adalah adanya jaminan kesederajatan bagi setiap orang di hadapan hukum (equality before the law). Oleh karena itu setiap orang berhak atas pengakuan, jaminan, perlindungan, dan kepastian hukum yang adil, serta perlakuan yang sama di hadapan hukum.

Dalam usaha memperkuat prinsip di atas, maka salah satu substansi penting perubahan Undang-Undang Dasar Negara Republik Indonesia Tahun 1945 telah membawa perubahan yang mendasar dalam kehidupan ketatanegaraan, khususnya dalam pelaksanaan Undang-Undang Dasar Negara 1945 yang memberikan jaminan bahwa Setiap orang berhak atas perlindungan diri pribadi, keluarga, kehormatan, martabat, dan harta benda yang di bawah kekuasaannya, serta berhak atas rasa aman dan perlindungan dari ancaman ketakutan untuk berbuat atau tidak berbuat sesuatu yang merupakan hak asasi. ${ }^{1}$

${ }^{1}$ Undang-Undang Dasar 1945 Perubahan Kedua BAB. XA Pasal 28G ayat (1), Pasal 28H Ayat (1 
Sejalan dengan perubahan Undang-Undang Dasar Negara Republik Indonesia Tahun 1945, Undang-Undang Nomor 5 Tahun 1960 tentang Peraturan Dasar PokokPokok Agraria dan beberapa peraturan perundang-undangan lainnya, Di dalam Negara Republik Indonesia, yang susunan kehidupan rakyatnya, termasuk perekonomiannya, terutama masih bercorak agraris, bumi, air dan ruang angkasa, sebagai karunia Tuhan Yang Maha Esa mempunyai fungsi yang amat penting untuk membangun masyarakat yang adil dan makmur sebagai yang kita cita-citakan. Dalam pada itu hukum agraria yang berlaku sekarang ini (Sebelum UUPA 1960), yang seharusnya merupakan salah satu alat yang penting untuk membangun masyarakat yang adil dan makmur tersebut, ternyata bahkan sebaliknya, dalam banyak hal justru merupakan penghambat daripada tercapainya cita-cita di atas.

Hukum agraria yang berlaku atas bumi, air dan ruang angkasa ialah hukum adat, sepanjang tidak bertentangan dengan kepentingan nasional dan Negara, yang berdasarkan atas persatuan bangsa, dengan sosialisme Indonesia serta dengan peraturan-peraturan yang tercantum dalam Undang-undang ini dan dengan peraturan perundangan lainnya,segala sesuatu dengan mengindahkan unsur-unsur yang bersandar pada hukum agama. ${ }^{2}$ Tanah merupakan karunai dari Tuhan Yang Maha Esa kepada umat manusia di muka bumi ini, Sebutan tanah dalam Bahasa kita dapat dipakai dalam berbagai arti, dalam arti yuridis tanah merupakan permukaan bumi, ${ }^{3}$ seperti diketahui bahwa manusia senantiasa akan selalu memerlukan tanah dan tidak akan terlepas dari tanah karena manusia dan tanah mempunyai hubungan yang sangat erat. Tanah yang terbatas jumlahnya dan populasi manusia semakin banyak menyebaban tidak seimbangnya antara manusia dengan tanah sehingga pengelolaan dan pemanfaat akan tanah juga harus diperhatikan. ${ }^{4}$

Dalam menyelenggarakan tertib hukum pertanahan, Pemerintah dalam hal ini adalah lembaga pemerintah nondepartemen yaitu ATR/BPN (Agraria dan Tata Ruang/Badan Pertanahan Nasional) mengeluarkan sebuah kebijakan yang disebut PTSL (Pendaftaran Tanah Sistematis Lengkap). Program ini dibentuk berdasarkan Peraturan Menteri Menteri Agraria dan Tata Ruang/Kepala Badan Pertanahan Nasional Republik Indonesia Nomor 35 Tahun 2016 Tentang Percepatan Pelaksanaan Pendafatarn Tanah Sistematis Lengkap dan diubah menjadi Peraturan Menteri Agraria dan Tata Ruang/Kepala Badan Pertanahan Nasional Nomor 1 Tahun 2017 Tentang Perubahan Atas Peraturan Menteri Agraria dan Tata Ruang/Kepala Badan Pertanahan Nasional Nomor 35 Tahun 2016 Tentang Percepatan Pelaksanaan Pendaftaran Tanah Sistematis Lengkap. Dalam Peraturan Menteri Agraria dan Tata Ruang/Kepala Badan Pemerintah Nasional Republik Indonesia Nomor 1 Tahun 2017 tentang Perubahan Atas Peraturan Menteri Agraria dan Tata Ruang/Kepala Badan Pertanahan Nasional Nomor 35 Tahun 2016 Tentang Percepatan Pelaksanaan Pendaftaran Tanah sistematis Lengkap, Pasal 1 ayat (1) menjelaskan: "Pendaftaran Tanah Sistematis Lengkap adalah kegiatan pendaftaran tanah untuk pertama kali yang dilakukan secara serentak bagi semua obyek pendafataran tanah di seluruh wilayah Republik Indonesia dalam satu wilayah

\footnotetext{
2)

2 UUPA Nomor 5 Tahun 1960 Pasal 5

${ }^{3}$ Budi Harsono. Hukum Agraria Indonesia Sejarah Pembentukan Undang-Undang Pokok Agraria, isi dan pelaksanaannya, Universitas Trisakti, 2013.

${ }^{4}$ Zainuddin, Zaki Ulya, Domein Verklaring Dalam Pendayagunaan Tanah di Aceh, Jurnal Hukum Samudra Keadilan, Volume 13 Nomor 1, Tahun 2018, hlm 18
} 
desa/kelurahan atau nama lainnya yang setingkat dengan itu, yang meliputi pengumpulan dan penetapan kebenaran data fisik dan data yuridis mengenai satu atau beberapa obyek pendafatarn tanah untuk keperluan pendaftarannya".

Pada tahun 2017 PTSL (Pendaftaran Tanah Sistematis Lengkap) pertama kali dilaksanakan yang sebelumnya dikenal masyarakat dengan nama PRONA (Proyek Operasi Agraria Nasional). Penerbitan sertifikat tanah dari program PTSL pada dasarnya tidak jauh berbeda dengan penerbitan sertifikat tanah melalui program PRONA, yaitu samasama dilaksanakan secara gratis, persyaratan dari pendafatran hak, dan penerbitan serta pelayanan dari Kantor Pertanahan (ATR/BPN). Yang membedakannya yaitu melalui program PRONA, pendataan penerima sertifikat PRONA dilakukan secara merata diseluruh desa dan kelurahan dalam satu kabupaten/kota dan PRONA hanya menerbitkan sertifikat tanah tidak menyeluruh pada semua bidang tanah yang tidak bersertifikat dalam satu daerah. Sedangkan program PTSL, pendataannya dilakukan terpusat di satu desa/kelurahan dan seluruh bidang tanah dalam daerah tersebut yang belum memiliki sertifikat akan dibuatkan. Dalam PTSL ini, tanah yang akan diterbitakn sertifikatnya akan di validitas dulu keberadaannya apakah tidak ada di dalamnya tanah yang bersengketa. Tanah yang bermasalah akan ditunda sampai kejelasan hukumnya ada.

Pendaftaran Tanah Sistematis Lengkap yang selanjutnya disingkat PTSL adalah kegiatan pendaftaran tanah untuk pertama kali yang dilakukan secara serentak bagi semua objek pendaftaran tanah di seluruh wilayah Republik Indonesia dalam satu wilayah desa/kelurahan atau nama lainnya yang setingkat dengan itu, yang meliputi pengumpulan data fisik dan data yuridis mengenai satu atau beberapa objek pendaftaran tanah untuk keperluan pendaftarannya.

Kemudian perlu juga dipahami, berlakunya Permen ATR/BPN dimaksudkan sebagai pedoman pelaksanaan kegiatan PTSL yang dilaksanakan desa demi desa di wilayah kabupaten dan kelurahan demi kelurahan di wilayah perkotaan yang meliputi semua bidang tanah di seluruh wilayah Indonesia. Berjalannya waktu dimulainya program Pendaftaran Tanah Sistematis Lengkap (PTSL) di Kabupaten Kendal yang diindikasi ada penyimpangan-penyimpangan didalam pelaksanaannya menjadi hal yang menarik untuk dapat dikaji serta dipelajari sejauh mana indikasi penyimpangan itu terjadi. Pendaftaran tanah dilakukan untuk mengetahui sejarah pencatatan administratif tanah tersebut, juga sebagai bukti serta dasar hukum atas kepemilikan sebuah bidang tanah bagi setiap pemiliknya yang kemudian menghasilkan suatu produk yakni berupa sertifikat sebagai bukti pemegang hak atas sebuah bidang tanah. ${ }^{5}$

Pasal 12 e jo Pasal 18 undang-undang Nomor 31 Tahun 1999 sebagaimana diubah undang-undang nomor 20 tahun 2001, pasal 55 ayat (1) ke-1 KUHP yang menjadi dakwaan Jaksa Penuntut Umum kepada para pelaku. Perkades Nomor 1 Tahun 2017 tentang Penggunaan Dana Pendampingan Pelaksanaan Program Sertfiktat Tanah melalui PTSL tertanggal 10 Pebruari 2017 dan Surat Keputusan Kepala Desa Sidomukti Nomor 1 Tahun 2017 tentang Pembentukan Panitia Pelaksanaan Program Sertifikat

\footnotetext{
5 Tomy Andi PS dan Hananto Widodo. Penegakan Hukum Terhadap Pelaku Tindak Pidana Pungutan Liar Yang Dilakukan Oleh Panitia Desa Pada Pendaftaran Tanah Sistematik Lengkap Di Desa X Kecamatan Duduksampeyan Kabupaten Gresik. https://ejournal.unesa.ac.id/index.php/novum/article/view/41570
} 
Masal melalui PTSL Tahun 2017 tertanggal 10 Pebruari 2017 yang menjadi dasar pelaksanaan sertifikat masal melalui PTSL perihal penetapan biaya dari para pemohon di Desa Sidomukti Kecamatan Weleri. ${ }^{6}$

Terbitnya Peraturan Kepala Desa dan Keputusan Kepala Desa yang tersebut diatas menjadi "pemicu "atau dimulainya praktek-praktek Pungutan Liar (Pungli) dalam pelaksanaan kegiatan sertifikat massal melalui PTSL. Membaca dan mengikuti perkembangan kasus yang terjadi di Desa Sidomukti Kecamatan Weleri Kabupaten Kendal terkait dengan pelaksanaan kegiatan sertikat massal melalui Pendaftaran Tanah Sistematis Lengkap (PTSL), bisa menjadi pemikiran dan kajian ilmiah penulis untuk memberikan sumbangsih pemikiran dalam penegakan hukum terhadap pelaku-pelaku kejahatan tindak pidana korupsi (Extra ordinary crime), sehingga pada saatnya nanti dalam penegakan hukum tidak dalam kerangka mencari-cari kesalahan pelaku namun lebih mengedepankan langkah-langkah penegakan hukum progresif dengan tetap berpegang pada norma undang-undang

\subsection{Rumusan Masalah}

Berdasarkan latar belakang sebagaimana telah diuraikan di atas, maka permasalahan yang muncul dan perlu mendapatkan jawaban dalam penelitian ini adalah:

1. Bagaimana Penegakan Hukum Tindak Pidana Korupai PTSL yang terjadi di Desa Sidomukti Kecamatan Weleri Kabupaten Kendal?

2. Bagaimana Peran Pemerintah dan Aparat Penegak Hukum dalam Berupaya Mencegah Terjadinya Tindak Pidana Korupsi PTSL Berbasis Nilai Keadilan?

\section{Metode Penelitian}

Penelitian ini merupakan penelitian hukum yuridis sosiologis yang menggunakan bahan-bahan hukum dan bahan-bahan non hukum dengan menggunakan metode pendekatan peraturan perundang-undangan serta pendekatan konseptual dan menghasilkan kajian yang bersifat deskriptif-analitis-yuridis. Pendekatan yang digunakan dalam penelitian ini yaitu pendekatan sosiologis yang dilakukan melalui pengamatan terhadap perilaku manusia, wawancara dan perilaku nyata yang dilakukan melalui pengamatan langsung mengenai kesadaran hukum masyarakat. Hal ini tentu saja terkait dengan pelaksanaan program PTSL dan proses penegakan hukum terhadap tindak pidana korupsi PTSL sesuai dengan prosedur yang tercantum dalam undang-undang.

Dalam penelitian ini yang melakukan penelitian di lapangan menggunakan hasil wawancara dari aparatur dan masyarakat langsung yang terkait dalam penelitian ini. Teknik Purposive (sengaja) digunakan dalam penentuan jumlah informan penelitian. Infroman dalam penelitian ini adalah:

1. Ketua Pengadilan Negeri Semarang atau yang ditunjuk mewakilinya.

\footnotetext{
${ }^{6}$ InfoPlus.id ,25 November 2019 "Program Sertifikata Massal di Kendal dikorupsi, Kades dan 2 Kadus Diadili"
} 
2. Kepala Kejaksaan Negeri Kendal atau yang ditunjuk mewakilinya.

3. Kepala Desa Sidomukti Weleri atau yang ditunjuk mewakilinya.

4. Ketua BPD Desa Sidomukti Weleri atau yang mewakilinya.

5. Ketua Kelompok Masyarakat (Pokmas) PTSL Tahun 2017 atau yang mewakilinya.

6. Pemohon Serifikat Massal melalui Pendaftaran Tanah Sistematis Lengkap (PTSL).

\section{Hasil dan Pembahasan}

\subsection{Penegakan Hukum Tindak Pidana Korupai PTSL yang terjadi di Desa Sidomukti Kecamatan Weleri Kabupaten Kendal}

Dari uraian permasalahan diatas, Pada hakekatnya penegakan hukum merupakan suatu proses dilakukan upaya-upaya untuk tegaknya atau berfungsinya norma-norma hukum sebagai pedoman perilaku dalam hubungan-hubungan hokum dalam kehidupan bermasyarakat dan berbangsa. Peraturan perundang-undangan sebagai Law in the book membutuhkan aparat penegak hukum untuk menjadikannya sebagai Law in action. Berlakunya Undang-Undang Nomor 8 Tahun 1981 tentang Kitab Undang-Undang Hukum Acara Pidana (KUHAP) telah membawa perubahan yang mendasar dalam proses penyelesaian perkara pidana, baik dalam konsepsi maupun implementasi. Sebagai konsekuensi dari perubahan tersebut para aparat pelaksana penegakan hukum melakukan upaya-upaya reorientasi atas sikap, tata cara dan tata pikiran dengan maksud agar mampu memainkan peran yang telah ditentukan. Peraturan yang mengatur tentang penegakan hukum dan perlindungan hukum terhadap keseluruhan harkat martabat manusia di dalam proses pidana pada hakekatnya telah diletakkan dalam Undang-Undang Nomor 48 tahun 2009 tentang Kekuasaan Kehakiman dan Undang-Undang Nomor 8 tahun 1981 tentang Kitab Undang-Undang Hukum Acara Pidana (KUHAP). ${ }^{7}$

Kitab Undang-Undang Hukum Acara Pidana (KUHAP) menganut konsep diferensiasi fungsional (penjelasan dan pembagian tugas wewenang antara jajaran aparat penegak hukum secara instansional) diantara komponen penegak hukum yang melaksanakan fungsi kekuasaan kehakiman dan penegakan hukum pada umumnya. Konsep diferensiasi fungsional yang dianut dalam KUHAP sebagaimana tercermin dari pembagian fungsi dan kewenangan aparat penegak hukum dalam tugas-tugas:

1. Penyidikan dan Penyelidikan

2. Penuntutan

3. Pemeriksaan disidang Pengadilan, dan

4. Pelaksanaan Putusan Hakim

Walaupun pada praktiknya konsep diferensiasi fungsional juga dapat terjadi pada satu institusi penegak hukum seperti Kejaksaan, dimana Jaksa sebagai penyidik tindak pidana khusus seperti Korupsi dan juga sekaligus sebagai Penuntut Umum. Konsepsi sistem peradilan pidana yang dianut dalam KUHAP tersebut sejalan dengan

\footnotetext{
${ }^{7}$ Bambang Sutiyoso, 2010, Reformasi Keadilan dan Penegakan Hukum di Indonesia, Yogyakarta, UII Press, hal.vii.
} 
diintrodusirnya konsepsi "Sistem Peradilan Pidana Terpadu" (Integrated Criminal Justice System) sebagai pengembangan dari model sistem peradilan pidana (criminal justice system model) yang pertama kali diperkenalkan di Amerika Serikat sekitar tahun 1960. Pendekatan sistem dalam mekanisme peradilan pidana menunjukkan adanya unsurunsur yang terdiri dari sub-sub sistem, yaitu sub sistem penyidikan, sub sistem penuntutan, sub sistem pemeriksaan di sidang pengadilan dan sub sistem pelaksanaan putusan pengadilan. Sistem peradilan pidana melibatkan komponen-komponen yang terdiri dari lembaga kepolisian, kejaksaan, pengadilan dan pemasyarakatan terpidana. Pendekatan sistem ini seharusnya memberikan perhatian yang sama terhadap semua komponen agar tercapai koordinasi dan sinkronisasi dalam penegakan hukum. ${ }^{8}$

Jaksa pada setiap kejaksaan mempunyai tugas pelaksanaan eksekusi putusan hakim yang telah memperoleh kekuatan hukum tetap, dan untuk keperluan itu didasarkan atas surat putusan hakim, atau kutipan putusan hakim, atau surat keterangan pengganti kutipan putusan hakim. Selain itu jaksa sebagai penuntut umum pada setiap kejaksaan juga mempunyai tugas melaksanakan penetapan hakum Pidana.

Tugas pelaksanaan eksekusi putusan hakim sebagai tahap terakhir perkara pidana dimaksudkan menjalankan pekerjaan melaksanakan putusan hakim dalam arti terbatas hanya untuk tugas eksekusi saja oleh Jaksa. Putusan hakim dapat ditetapkan dari berbagai jenis pidana yang terdapat di dalam kitab Undang-Undang Hukum Pidana atau aturan hukum lainnya yang sah, dan selanjutnya pelaksanaan putusan berbagai jenis pidana tersebut diatur lebih lanjut dalam peraturan perundangan mengenai pelaksanaan pidana.

Penegakan hukum yang ada di masyarakat modern tidak hanya diartikan dalam arti sempit tetapi juga dalam arti luas, seperti di Indonesia penegakan hukum dikaitkan dengan unsur manusia dan lingkungan sosialnya. Usaha penegakan hukum sejalan dengan prinsip NKRI yaitu Pancasila9. Tegaknya hukum merupakan suatu prasarat bagi sebuah negara hukum, penegakan hukum selalu melibatkan manusia-manusia didalamnya dan dengan demikian akan melibatkan tingkah laku manusia juga. Upaya penegakan hukum pidana pada hakikatnya juga merupakan bagian dari usaha penegakan hukum dan sering dikatakan sebagai politik atau kebijakan hukum pidana yang merupakan bagian dari kebijakan penegakan hukum (Law Enforcement Police). ${ }^{10}$

Berkaitan dengan penegakan hukum dalam ranah hukum agrarian ini, tidak bisa lepas dari amanat Undang-Undang Pokok Agraria yakni guna mewujudkan kepastian hukum, maka diselenggarakan pendaftaran tanah Indonesia. ${ }^{11}$ Dalam Pasal 19 ayat (1) dan ayat (2) Undang-Undang Nomor 5 Tahun 1960 merupakan dasar yang memberikan arahan dalam pembentukan dari Peraturan Pemerintahan tentang pendaftaran tanah. ${ }^{12}$

\footnotetext{
${ }^{8}$ Andi Hamzah, 2010 s.d 2016, Hukum Acara Pidana Indonesia, Penerbit Sinar Grafika, Jakarta.

${ }^{9}$ Achmad Ali. 2002. Menguak Tabir Hukum, (Suatu Kajian Filosofis danSosiologis). Jakarta: PT. Toko Gunung Agung.hlm. 44

${ }^{10}$ Barda Nawawi Arief, Bunga Rampai Kebijakan Hukum Pidana, PT. Citra Aditya Abadi, Jakarta, 2014, hlm. 29.

${ }^{11}$ Tuahta Rivaldo Sabaqal Tarigan dkk, Jurnal Ilmiah Mahasiswa Meukuta Alam, Volume 1 Nomor 2, Desember 2019, Pelaksanaan Program Pendaftaran Tanah Sistematis Lengkap (PTSL) Guna Mencapai Kepastian Hukum Atas Kepemilikan Hak Atas Tanah (Studi Kasus Di Kecamatan Langsa Timur). http://jim.unsam.ac.id/index.php/Meukutaalam/article/view/38

12 Adrian, Sutedi. 2014. Sertifikat Hak Atas Tanah, Jakarta, Sinar Grafika, hlm 10
} 
Dalam penelitian ini, penulis melakukan wawancara dan penelitian data yang ada (Permen ATR/BPN, SKB 3 Menteri, Perbup, Perkades dan S.K Kepala Desa ) yang menjadi dasar pelaksanaan kegiatan sertifikat massal melalui Pendaftaran Tanah Sistematis Lengkap (PTSL) Tahun 2017 di Desa Sidomukti Kecamatan Weleri Kabupaten Kendal, penulis menemukan beberapa hal yang menjadi persoalan kericuhan atau kegaduhan pelaksanaan kegiatan Pendaftaran Tanah Sistematis Lengkap (PTSL) Tahun 2017 di Desa Sidomukti Kecamatan Weleri Kabupaten Kendal.

Beberapa hal yang perlu menjadi pembahasan dan konsen penulis dalam pelaksaanaan kegiatan PTSL di Desa Sidomukti Kecamatan Weleri Kabupaten Kendal, antara lain:

1. Persiapan Kegiatan Program Pendaftaran Tanah Sistematis Lengkap (PTSL)

Desa Sidomukti Kecamatan Weleri. Sebagaimana persiapan pelaksanaan kegiatankegiatan didesa pada umumnya Musyawarah Desa (Majelis Tinggi Desa) merupakan forum permusyawaratan yang diikuti oleh Badan Permusyawaratan Desa, Pemerintah Desa, dan unsur masyarakat Desa untuk memusyawarahkan hal yang bersifat strategis dalam penyelenggaraan Pemerintahan Desa untuk menyepakati/merumuskan apa yang nantinya menjadi kebijakan desa, sebagai pondasi serta dasar pelaksanaan kegiatan Desa. ${ }^{13}$ Begitu juga dalam menetapkan dasar untuk pelaksanaan persiapan kegiatan sertifikat massal melalui Pendaftaran Tanah Sistematis Lengakap (PTSL) Tahun 2017 Di Desa Sidomukti Kecamatan Weleri. Dalam melaksanakan kegiatan persiapan PTSL sebenarnya apa yang sudah dijalankan Pemerintahan Desa Sidomukti sudah menjalankan tahapan-tahapannya, seperti:

1) Melaksanakan Musyawarah Desa yang dituangkan dalam Berita Acara (BA) Persetujuan Bersama Kepala Desa dan BPD Desa Sidomukti Kecamatan Weleri Kabupaten Kendal tentang Biaya Pendampingan Pelaksanaan Program Sertifikat Tanah Melalui Pendaftaran Tanah Sistematis Lengkap (PTSL) Desa Sidomukti Tahun 2017.

2) Pembuatan Peraturan Desa tentang Biaya Pendampingan Pelaksanaan Program Sertifikat Tanah Melalui Pendaftaran Tanah Sistematis Lengkap (PTSL) Desa Sidomukti Tahun 2017 dan diundangkan oleh PLT. Sekdes desa Sidomukti pada tanggal 15 Januari 2017.

3) Berita Acara dan yang kemudian dilanjutkan dengan membuat Peraturan Desa (Perdes) yang isinya tentang jumlah biaya yang dibebankan kepada masyarakat (Pemohon Sertifikat).

4) Menimbang diktum a dan b pada Peraturan Kepala Desa (Perkades) Nomor 1 Tahun 2017 tentang Penggunaan Dana Pendamping Pelaksanaan Program Sertifikat Tanah Melalui Pendaftaran tanah Sistematis Lengkap (PTSL) Desa Sidomukti Tahun 2017 disebutkan, bahwa guna melaksanakan amanat Peraturan Desa Pasal 6 Ayat (2), maka perlu mengatur penggunaan dana pendamping pelaksanaan program sertifikat tanah melalui Pendaftaran Tanah Sistematis Lengkap (PTSL) Desa Sidomukti Tahun 2017, dan bahwa sesuai dengan hasil musyawarah bersama antara Pemerintah Desa dengan Badan Pemusyawaratan Desa (BPD) Desa Sidomukti yang dilaksanakan pada tanggal 10 Pebruari 2017 yang membahas tentang penetapan biaya dan penggunaan

${ }^{13}$ Undang-Undang No, 6 Tahun 2014 Pasal 55-56 
dana pendamping pelaksanaan program PTSL Desa Sidomukti Tahun 2017, maka perlu merumuskan hasil musyawarah bersama sebagaimana dimaksud ke dalam Peraturan Kepala Desa .

5) Penetapan Peraturan Desa Nomor 10 Tahun 2017 tentang Perubahan Peraturan Desa Nomor 1 Tahun 2017 tentang Biaya Pendamping Pelaksanaan Program Sertifikat Tanah Melalui Pendaftaran Tanah Sistematis Lengkap (PTSL) Desa Sidomukti Tahun 2017

Dari hasil penelitian di Desa Sidomukti serta menganalisa dokumen/data yang ada, secara administrasi program sertifikat melalui Pendaftaran Tanah Sistematis Lengkap (PTSL) Tahun 2017 Desa Sidomukti Kecamatan Weleri Kabupaten Kendal tidak menyimpang dari peraturan dan perundang-undangan yang ada, karena salah satu bentuk lain dari proses untuk mewujudkan good administration adalah dengan membangun system dimana administrasi public memiliki instrument untuk mengawasi dan mengendalikan dirinya sendiri. Hal tersebut untuk memberikan standar yang sama-sama dipahami, baik oleh administrasi public maupun masyarakat, terkait tindakan dan kebijakan yang dilakukan oleh administrasi public. Instrumen tersebut berupa prosedur administratif ${ }^{14}$ (administrative procedure).

2. Proses Awal Penegakan Hukum

Pada hakekatnya penegakan hukum merupakan suatu proses dilakukan upaya-upaya untuk tegaknya atau berfungsinya norma-norma hukum sebagai pedoman perilaku dalam hubungan-hubungan hukum dalam kehidupan bermasyarakat dan berbangsa. Peraturan perundang-undangan sebagai Law in the book membutuhkan aparat penegak hukum untuk menjadikannya sebagai Law in action

3. Proses Penyidikan Oleh Pihak Kejaksaan

Dari hasil wawancara dengan Jampidsus Kejaksaan Negeri Kendal, bahwa kasus PTSL di Desa Sidomukti Kecamatan Weleri tidak adanya unsur kerugian Negara yang ditimbulkan akibat perbuatan para tersangka, sehingga Jaksa Penuntut Umum membuat serta menerapkan surat dakwaan menggunakan Pasal 12 e jo Pasal 18 undang-undang Nomor 31 Tahun 1999 sebagaimana telah diubah dan ditambah dalam undang-undang nomor 20 tahun 2001, pasal 55 ayat (1) ke-1 KUHP. Keengganan Jaksa Penyidik maupun Penuntut Umum untuk menerapkan ketentuan Pasal 2 ayat (1) atau Pasal 3 Undang-Undang RI Nomor 31 Tahun 1999 tentang Pemberantasan Tindak Pidana Korupsi sebagaimana telah diubah dan ditambah dalam Undang-Undang RI Nomor 20 Tahun 2001 juga terjadi hampir disemua unit kerja Kejaksaan diwilayah hukum Kejaksaan Tinggi Hal ini dapat terjadi dimungkinkan karena:

a. Adanya pemahaman bahwa uang yang ditarik sebagai Pungli oleh pelaku kejahatan bukan bersumber dari negara (APBN/APBD).

14 Dinoroy Marganda Aritonang, Aspek Hukum Penyelenggaraan Administrasi Publik di Indonesia, PT. Rafika Aditama Bandung, cetakan kesatu April 2019, hlm 121-128. 
b. Tidak mau repot dengan mekanisme pengajuan Rentut (RencanaTuntutan) yang berlaku diinternal Kejaksaan terutama pada penerapan Pasal 2 ayat (1) atau Pasal 3 UU. Tipikor.

Keengganan Jaksa Penyidik selaku penyidik kasus-kasus Tindak Pidana Korupsi dengan modus operandi Pungutan Liar (Pungli) pada programprogram kerja pemerintah dan keengganan Penuntut Umum untuk memberikan petunjuk (P-18, P-19) pada saat melakukan penelitian berkas perkara Tindak Pidana Korupsi dimaksud, menyebabkan penanganan perkara Tindak Pidana Korupsi tidak secara maksimal dilakukan dan lebih parahnya lagi kurang memberikan efek jera dan daya tangkal bagi pelaku kejahatan.

4. Proses Persidangan dan Putusan Di Tingkat Pertama dan Kasasi

Dalam proses uji kebenaran lewat proses peradilan yang dalam hal ini digelar di Pengadilan Tipikor Pengadilan Negeri Semarang. Beberapa hal yang menjadi problem pelaksaanaan kegiatan PTSL Di Desa Sidomukti Kecamatan Weleri Kabupaten Kendal adalah sebagai berikut:

a. Kelengkapan dokumen

b. Kebijakan Pemerintah Daerah Kabupaten Kendal untuk memberikan subsidi kepada pemohon PTSL sesuai dengan apa yang sudah termaktub dalam Surat Keputusan Bersama Tiga Menteri yaitu Menteri Agraria dan Tataa Ruang/Badan Pertanahan Nasional Nomor, dan Menteri Dalam Negeri serta Menteri Desa, Pembangunan Daerah Tertinggal dan Transmigrasi No. 25/SKB/V/2017, No. 590-3167A, No. 34 Tahun 2017 tentang Pembiayaan Persiapan Pendaftaran Tanah Sistematis Lengkap pada Diktum Ketujuh menginstruksikan pembebanan biaya untuk wilayah V yaitu Bali dan Jawa sebesar Rp 150.000,- dan bagi daerah yang tidak mampu memberikan subsidi dapat dibebankan kepada masyarakat.

Terhadap pelaku Tindak Pidana Korupsi dengan modus melakuan Pungutan Liar (Pungli) saat dilakukan upaya penegakan hukumnya dengan menerapkan ketentuan Pasal 12 e jo Pasal 18 undang-undang Nomor 31 Tahun 1999 sebagaimana diubah undang-undang nomor 20 tahun 2001, pasal 55 ayat (1) ke-1 KUHP yang digunakan untuk menjerat para pelaku, namun dalam praktiknya dipersidangan Penuntut Umum mengalami kesulitan dalam membuktikan adanya unsur "memaksa" yang dilakukan oleh pelaku tindak pidana. Hambatan dan kesulitan yang dihadapi tersebut membuat aparat penegak hukum yang menangani kasus Tindak Pidana Korupsi dengan modus melakukan perbuatan Pungutan Liar (Pungli) harus berpikir lebih kritis untuk membuat terobosan melapis pasal - pasal baru yang dipersangkakan kepada pelaku, tidak lagi terbatas pada Pasal 12 huruf e sebagaimana tersebut di atas, sehingga pada saatnya nanti dalam penegakan hukum tidak dalam kerangka mencari-cari kesalahan pelaku namun lebih mengedepankan langkah-langkah penegakan hukum progresif dengan tetap berpegang pada norma undang-undang.

Maka akhirnya setelah diuji dalam proses peradilan tingkat pertama dan Hasil Putusan Pengadilan Negeri Semarang yang menangani perkara Kasus Tindak Pidana Korupsi sertifikat massal melalui Pendaftaran Tanah Sistematis Lengkap (PTSL) Tahun 2017 Desa Sidomukti Kecamatan Weleri dengan Hasil Putusannya Nomor 79/Pidsus-TPK/2019 Pengadilan Negeri Semarang tanggal 26 Februari 2020 yang Isi keputusan tersebut menyatakan, bahwa terdakwa Sugiyanto Kepala Desa 
dkk tidak terbukti secara sah dan tidak bersalah atau tidak melakukan tindak pidana seperti dalam dakwaan dari Jaksa Penuntut Umum.

Pun demikian dalam putusan kasasi yang diajukan Jaksa Penuntut Umum (JPU), Majelis Hakim MA yang menangani perkara Kasus Tindak Pidana Korupsi sertifikat massal melalui Pendaftaran Tanah Sistematis Lengkap (PTSL) Tahun 2017 Desa Sidomukti Kecamatan Weleri, Hasil Putusan perkara bernomor 2963K/PID.SUS/2020 pada 8 Desember 2020 MAR terbukti melakukan pungutan liar (Pungli). Tapi dalam putusan kasasi MA, untuk berkas kasus PAR Ketua Kelompok Masyarakat (Pokmas) dinyatakan bebas. Alias, MA menolak permohonan JPU. Sedangkan untuk kasasi Mantan Kades SGY, saat ini masih proses di MA.

Penjelasan tersebut diatas menjadi problem tersendiri tentang penanganan perkara Tindak Pidana Korupsi tidak secara maksimal dilakukan dan lebih parahnya lagi kurang memberikan efek jera dan daya tangkal bagi pelaku kejahatan. Mencermati fakta aktual yang terjadi dalam upaya pemberantas dan penegakan hukum tindak pidana korupsi yang terjadi dalam berbagai departemen dan Instansi maupun lembaga Negara bak kasus-kasus nasional maupun daerahdaerah dengan berbagai modus operandi belum menunjukan hasil yang optimal, bahkan terkesan masih terjadi diskriminatif perlakuaan aparat penegak hukum mulai dari proses penyidikan, penahanan, penuntutan sampai dengan lahirnya putusan pengadilan sangat kontrovesial, dan semuanya menambah daftar kelabu dan kekecewaan masyarakat dan semakin kaburnya cita-cita penegakan hukum yang berkeadilan serta bermartabat.

5. Perlindungan Terhadap Korban

Berkaitan dengan perlindungan korban yang perlu diperhatikan, dapat melakukan beberapa mekanisme, yakni melakukan permohonan restitusi melalui LPSK (Lembaga Perlindungan Saksi dan Korban) dan mengajukan gugatan perbuatan melawan hukum ke Pengadilan Negeri dalam rangka mencari kepastian hukum mengenai hak warga Desa Sidomukti Kecamatan Weleri Kabupaten Kendal untuk mendapatkan sertifikat tanah. Warga bisa menempuh jalur perdata untuk mengembalikan haknya, karena permasalahan ganti kerugian tersebut bukan menjadi kewenangan dari Majelis Hakim

\subsection{Peran Pemerintah dan Aparat Penegak Hukum dalam Berupaya Mencegah Terjadinya Tindak Pidana Korupsi PTSL Berbasis Nilai Keadilan}

Lahirnya Undang-Undang Tindak Pidana Korupsi Nomor 3 Tahun 1971 yang kemudian dicabut dan disempurnakan dengan lahirnya Undang-Undang Nomor 31 Tahun 1999 kemudian dengan Undang-Undang Nomor 20 Tahun 2021 lebih disempurnakan lagi bukan menjadi jaminan optimalnya penegakan hokum tindak pidana korupsi, seklaipun harus diakui bahwa secara normative subtantif undang-undang tersebut telah banyak mengalami kemajuan dengan berbagai karakteristik sebagai tindak pidana khusus yang diatur dalam KUH Pidana.

Peran serta Pemerintah Daerah Propinsi dan Daerah Kabupaten/Kota dalam hal ini Pemerintah Propinsi Jawa Tengah dan Pemerintah Daerah Kabupaten Kendal pada persoalan/permasalahan program kegiatan sertifikat melalui 
Pendaftaran Tanah Sistematis Lengkap (PTSL) di Desa Sidomukti Kecamatan Weleri sangat besar sekali dan Pemerintah Daerah juga bertanggungjawab terhadap kekacauan serta kegaduhan program (Pendaftaran Tanah Sistematis Lengkap) yang menjadi unggulan Pemerintah Pusat untuk memberikan kesejahteraan bagi masyarakat, terbukti dengan dikeluarkannya PeraturanPeraturan tersebut di atas. Akan tetapi, Pemerintah Kabupaten Kendal sampai dengan tulisan ini dibuat baru mengeluarkan/menerbitkan Peraturan Bupati Kendal Nomor 3 Tahun 2018 Tentang Pembiayaan Persiapan Pelaksanaan Pendaftaran Tanah Sistematis Lengkap Bagi Masyarakat Di Kabupaten Kendal. Peraturan Bupati Tersebut sifatnya hanya meneruskan apa yang sudah termaktub dalam peraturan yang diatasnya dan belum mengindahkan serta mengambil langkah-langkah seperti apa yang menjadi perintah Peraturan yang diatasnya dan Peraturan Bupati keluar setelah ada persoalan hukum yang terjadi di Desa Sidomukti terkait dengan pembiayaan program sertifikat melalui Pendaftaran Sistematis Lengkap (PTSL) yang dibebankan kepada masyarakat pemohon melalui kebijakan desa.

Peraturan Bupati Kendal Nomor 3 Tahun 2018 Tentang Pembiayaan Persiapan Pelaksanaan Pendaftaran Tanah Sistematis Lengkap Bagi Masyarakat Di Kabupaten Kendal yang dikeluarkan pada tahuan 2018 setelah ada kegaduhan dan kericuhan tentang Pendaftaran Tanah Sistematis Lengkap (PTSL) di desa-desa yang ada diwilayah administratif kabupaten Kendal menurut penulis bukan merupakan jawaban yang solutif terkait dengan biaya persiapan Pendaftaran Tanah Sistematis Lengkap (PTSL) namun hanyalah merupakan pengguguran kewajiban Pemerintah Daerah (Kabupaten Kendal) atas perintah peraturan diatasnya.

Pada pembukaan Undang-Undang Dasar Negara Republik Indonesia 1945 Republik Indonesia sudah menjelasakan, bahwa tujuan bernegara (Negara Indonesia) melindungi segenap bangsa Indonesia dan seluruh tumpah darah Indonesia dan untuk memajukan kesejahteraan umum, mencerdaskan kehidupan bangsa dan ikut melaksanakan ketertiban dunia yang berdasarkan kemerdekaan, perdamaian abadi dan keadilan sosial.

Dalam konteks Democratic Government dan Rule of law (Negara Hukum), peran dan fungsi pemerintah diaturan dilaksanakan berdasarkan peraturan perundangundangan atau hukum dalam arti luas. Pelaksanaan administrasi publik tanpa regulasi yang menyetujuinya akan menyebabkan perbuatan atau kebijakan yang diambil menjadi illegal. Fungsi peraturan dalam adminstrasi publik bukan hanya sebagai panduan atau pedoman pelaksanaan tetapi juga sebagai instrument akuntabilitas bagi adminstrasi publik.

Lahirnya Komisi Pemberantas Korupsi berdasarkan Undang-Undang Nomor 30 Tahun 2002 dengan berbagai kewenangan sangat luas serta terbentuknya Tim Tastipikor ${ }^{15}$

\footnotetext{
${ }^{15}$ Keputusan Presiden Republik Indonesia Nomor 11 Tahun 2005 Tentang Tim Koordinasi Pemberantasan Tindak Pidana Korupsi
} 


\section{Kesimpulan}

Dari artikel diatas dapat diambil kesimpulan bahwa.

1. Tindak Pidana Korupsi bisa saja dilakukan dalam praktek diluar hukum pidana, seperti pada tinjauan kasus tindak pidana korupsi yang terjadi dalam proses Pendaftaran Tanah Sistematis Lengkap (PTSL) di Desa Sidomukti, Weleri, Kabupaten Kendal. Dalam proses PTSL secara administrasi masuk dalam ranah hukum perdata, namun makin banyaknya modus operandi maka adanya kesempatan bisa menjadikan alasan seseorang melakukan tindak pidana korupsi baik itu dilakukan oleh swasta maupun orang perorangan dalam hal menjalankan tugasnya sebagai aparat desa atau apparatus sipil negara.

2. Penerapan hukum pidana diharapkan memberikan efek jera bagi pelaku tindak pidana korupsi dan diperlukan peran Pemerintah serta Apat Penegak Hukum guna mencegah terjadinya tindak pidana korupsi sehingga diperlukan pengawasan hingga lingkup Desa dalam penyelenggaraan tugas dan kewajiban aparat desa ataupun Aparatur Sipil Negara.

\section{DAFTAR PUSTAKA}

\section{A. Buku}

Adrian, Sutedi. 2014. Sertifikat Hak Atas Tanah, Jakarta, Sinar Grafika

Ali. Achmad 2002. Menguak Tabir Hukum, (Suatu Kajian Filosofis danSosiologis). Jakarta: PT. Toko Gunung Agung

Hamzah Andi, 2010, Hukum Acara Pidana Indonesia, Penerbit Sinar Grafika, Jakarta.

Harsono Budi. 2013. Hukum Agraria Indonesia Sejarah Pembentukan Undang-Undang Pokok Agraria, isi dan pelaksanaannya, Universitas Trisakti.

Marganda Aritonang Dinoyo, Aspek Hukum Penyelenggaraan Administrasi Publik di Indonesia, PT. Rafika Aditama Bandung, cetakan kesatu April 2019,

Nawawi Arief Barda. 2014. Bunga Rampai Kebijakan Hukum Pidana, Jakarta. PT. Citra Aditya Abadi.

Poernomo Bambang. 2016. Kapita Selekta Sistem Peradilan Pidana, Universitas Jayabaya.

Sutiyoso Bambang, 2010, Reformasi Keadilan dan Penegakan Hukum di Indonesia, Yogyakarta, UII Press, hal.vii.

\section{B. Peraturan Perundang-undangan}

Kitab Undang-Undang Hukum Pidana

Kitab Undang-Undang Hukum Acara Pidana

Undang-Undang Pokok Agraria Nomor 5 Tahun 1960 tentang Peraturan Dasar PokokPokok Dasar Agraria

Undang-Undang No, 6 Tahun 2014 tentang Desa

Keputusan Presiden Republik Indonesia Nomor 11 Tahun 2005 Tentang Tim Koordinasi Pemberantasan Tindak Pidana Korupsi 


\section{Artikel Jurnal}

Tomy Andi PS dan Hananto Widodo. Penegakan Hukum Terhadap Pelaku Tindak Pidana Pungutan Liar Yang Dilakukan Oleh Panitia Desa Pada Pendaftaran Tanah Sistematik Lengkap Di Desa X Kecamatan Duduksampeyan Kabupaten Gresik. Novum:Jurnal Hukum.Universitas Negeri Surabaya. https://doi.org/10.2674/novum.v0i0.41570

Tuahta Rivaldo Sabaqal Tarigan dkk, Jurnal Ilmiah Mahasiswa Meukuta Alam, Volume 1 Nomor 2, Desember 2019, Pelaksanaan Program Pendaftaran Tanah Sistematis Lengkap (PTSL) Guna Mencapai Kepastian Hukum Atas Kepemilikan Hak Atas Tanah (Studi Kasus Di Kecamatan Langsa Timur). http://jim.unsam.ac.id/index.php/Meukutaalam/article/view/38

Zainuddin, Zaki Ulya, Domein Verklaring Dalam Pendayagunaan Tanah di Aceh, Jurnal Hukum Samudra Keadilan, Volume 13 Nomor 1, Tahun 2018

\section{Website Resmi}

www.InfoPlus.id ,25 November 2019 “Program Sertifikat Massal di Kendal dikorupsi, Kades dan 2 Kadus Diadili" 